\title{
Factor Analysis of Obstacles Restraining Productivity Improvement Programs in Manufacturing Enterprises in Oman
}

\author{
Hamdi A. Bashir, ${ }^{1}$ Khalid Alzebdeh, ${ }^{2}$ and Amur M. A. Al Riyami ${ }^{2}$ \\ ${ }^{1}$ Department of Industrial Engineering and Engineering Management, University of Sharjah, Sharjah, United Arab Emirates \\ ${ }^{2}$ Department of Mechanical and Industrial Engineering, Sultan Qaboos University, Muscat, Oman \\ Correspondence should be addressed to Hamdi A. Bashir; hamdi.bashir@mail.mcgill.ca
}

Received 14 June 2014; Revised 17 October 2014; Accepted 20 October 2014; Published 13 November 2014

Academic Editor: Enrico Cagno

Copyright (c) 2014 Hamdi A. Bashir et al. This is an open access article distributed under the Creative Commons Attribution License, which permits unrestricted use, distribution, and reproduction in any medium, provided the original work is properly cited.

\begin{abstract}
Manufacturing enterprises can face obstacles that make productivity improvement efforts ineffective or even prevent improvement operations. This paper reports on an investigation of the internal obstacles restraining productivity improvement programs in the manufacturing enterprises of developing countries, using Oman as a case study. Data required for this study were collected through a questionnaire given to production and operations managers at 51 manufacturing enterprises in Oman. The results of applying factor analysis to a dataset of 15 obstacles showed that these obstacles can be reduced to three major factors. Ranked according to their importance, these factors are poor management practices, employee job dissatisfaction, and poor human resource management. The findings of this research are of value to production and operations managers of manufacturing enterprises who are interested in conducting productivity improvement programs not only in Oman but also in developing countries with environments similar to that of Oman, such as the Gulf Cooperation Council (GCC) countries.
\end{abstract}

\section{Introduction}

Productivity is one of the most widely used tools for evaluating, monitoring, and improving the performance of industries and national economies. At a national level, productivity indicates how well an economy uses its resources in producing goods and services. A decline in productivity can lead to slow economic growth and high inflation. On the other hand, improved productivity can lead to a higher rate of economic growth and higher living standards for a nation [1]. At an organizational level, productivity measures how well an organization converts input resources (labor, materials, machines, etc.) into goods and services. A decline in productivity will result in an increase in costs and therefore deterioration in the competitive position of an organization. On the other hand, an improvement in productivity can lead to a decrease in the costs and duration of production, an improvement in quality, and therefore a growth in market share. According to Kazaz and Ulubeyli [2], productivity is one of the most important factors affecting the overall performance of any organization, large or small. It is defined as a measure of the relationship between the physical volume of goods and services produced and the resources used in the production processes adopted by an economy. Productivity is also a measure of the efficiency with which employees and capital and natural resources are combined in an economy.

In addition to assessing its performance, an organization can use productivity measures to

(i) compare its performance with that of competitors,

(ii) assess the relative performance of its individual departments,

(iii) compare the relative benefits of various inputs,

(iv) plan the most effective use of resources.

It is possible to define a variety of productivity measures, depending on whether the measurement of variables is performed in physical or financial terms and which resource inputs are selected for performance evaluation [3]. Generally, productivity measures can be classified into the following categories:

(i) partial factor productivity: the ratio of output to one type of input (labor, capital, material, or energy), 
(ii) multifactor productivity: using more than one input,

(iii) total factor productivity: using all the inputs of production (labor, capital, material, and energy).

There are several ways to improve productivity in organizations. However, the implementation of productivity improvement programs is not always successful. Factors that make productivity improvement efforts ineffective-or even prevent improvement operations from taking place-are called obstacles to productivity improvement [4]. There are two types of obstacles: internal and external. Internal obstacles are those that originate inside the organization. Managers and stakeholders can usually control these. Examples of such obstacles include a lack of top management support and a lack of time and other resources. On the other hand, external obstacles are those that stem from outside the organization. Examples of these factors include governmental regulations and market conditions.

\section{Related Research}

Today's intense competition forces organizations to examine how they can improve productivity. Consequently, several studies have investigated factors affecting productivity in various industries, for example, construction [2, 5-10], manufacturing $[11,12]$, and service [13-17]. It is beyond the scope of this paper to review these studies. However, because they address the issue of obstacles to productivity improvement programs, the studies by Hoffman and Mehra [18] and Rantanen [4] are perhaps the most relevant studies.

In order to identify the critical factors that are potentially "fatal" to productivity improvement programs, Hoffman and Mehra [18] conducted a two-stage study. The first stage consisted of forming an expert panel to be interviewed via the Delphi method. The panel had five participants, each having significant experience in productivity-related issues. On the basis of the Delphi method results and existing literature, 20 factors were identified as possible obstacles to productivity improvement programs. These factors were then used in the second stage of the study to design a questionnaire that would solicit responses from 100 randomly selected production and operations managers within the regional American Production and Inventory Control Society (APICS) group regarding the critical productivity factors that influence the outcomes of productivity improvement programs. Based on 41 responses, it was concluded that seven critical factors can cause the failure of a productivity improvement program. These factors relate to top management, planning, coordination, communication, training, and employee relationships.

Rantanen [4] conducted a survey investigating the major internal obstacles to productivity improvement in small industrial firms in two regions of Finland: Päijät-Häme and Pirkanmaa. On the basis of analyzing data collected from 141 respondents, it was concluded that the major obstacles to productivity improvement programs can be classified into two major categories: (1) factors involving the lack of time and other resources and (2) shortcomings in knowledge and education regarding productivity.

\section{Motivation and Research Objectives}

The above literature review revealed that although several studies have investigated factors affecting productivity both positively and negatively, only the studies by Hoffman and Mehra [18] and Rantanen [4] have dealt with the issue of obstacles to productivity improvement. However, these two studies addressed issues relating to the obstacles to productivity improvement programs in two developed countries. Since they are contextual, that is, they vary from one country to another, there is a need to investigate the obstacles restraining productivity improvement programs in other countries.

The aim of this study was to investigate the internal obstacles to productivity improvement programs in manufacturing enterprises in the developing country of Oman. Based on the International Standard Classification used by the United Nations, manufacturing enterprises convert the outputs of primary enterprises (those that cultivate and exploit natural resources) into products such as metals, foods, textiles, beverages, and consumer appliances [19].

For Oman, the manufacturing sector is an important source of national income. In 2011, this sector contributed $10.3 \%$ to GDP, as compared to $4.7 \%$ in 1995 . Moreover, manufacturing is a key sector of the government's "Vision 2020" economic diversification plan. By 2020, it is expected to contribute $15 \%$ of GDP [20].

\section{Methodology}

The methodology applied to analyze the internal obstacles restraining productivity is the subject of this section. It describes the method of collecting data as well as the analysis tools.

4.1. Questionnaire Design and Data Collection. In order to control the data collected and provide easier analysis, it was decided to use a questionnaire with closed-type question forms. Most of the questions were based on a five-point Likert scale. The clarity and completeness of the questions were ensured by conducting a pilot study that included eight manufacturing enterprises. The responses received from these organizations were used to refine the questionnaire. The refined questionnaire consisted of two major parts. The first part contained questions relating to the organization profile, including the type of products that the industry manufactures. The second part was designed to address the subject of this study: which obstacles restrain productivity improvement programs? These obstacles are as follows:

(i) $\mathrm{O}_{1}$ : insufficient investment in workforce training,

(ii) $\mathrm{O}_{2}$ : poor financial controls and/or information systems,

(iii) $\mathrm{O}_{3}$ : weak middle managers,

(iv) $\mathrm{O}_{4}$ : decline of the work ethic,

(v) $\mathrm{O}_{5}$ : no clear connection between employee effort and rewards,

(vi) $\mathrm{O}_{6}$ : insufficient capital for improving plants and equipment,

(vii) $\mathrm{O}_{7}$ : poor employee relations, 
(viii) $\mathrm{O}_{8}$ : weakness in industrial and manufacturing engineering,

(ix) $\mathrm{O}_{9}$ : a piecemeal, unplanned approach to improving productivity,

(x) $\mathrm{O}_{10}$ : inadequate/ineffective coordination among departments or functional areas,

(xi) $\mathrm{O}_{11}$ : insufficient investment in management and supervisor training and development,

(xii) $\mathrm{O}_{12}$ : poorly trained supervisory personnel in the area of productivity-related problems,

(xiii) $\mathrm{O}_{13}$ : high worker turnover,

(xiv) $\mathrm{O}_{14}$ : lack of workforce loyalty,

(xv) $\mathrm{O}_{15}$ : impossibility of program implementation.

Using a five-point Likert scale ranging from 1 (Strongly Disagree) to 5 (Strongly Agree), respondents were asked to indicate the extent to which they agreed that each of the above was an obstacle to productivity improvement programs in their organizations. It is worth noting that this study was designed to be exploratory, and the works of Hoffman and Mehra [18] and Rantanen [4] and the results of the pilot study were the basis for selecting these 15 obstacles.

A very important step in the data collection process is selecting the sample size. The most effective way to ensure the generality of results is to use a sufficiently large sample size. However, in this type of research, because the size of the population of interest is small, the sample size can also be relatively small. In addition to population size, the sample size depends on other factors, such as the minimum acceptable level of precision and the confidence level. In this study, the sample size was determined based on the most widely used rule-of-thumb, "use as many subjects as you can get and you can afford" [21]. Based on this rule, the questionnaire was sent to a random sample of 80 production/operations managers at manufacturing enterprises in Oman. They were asked to complete and return the questionnaire if they had ever implemented or tried to implement a productivity improvement program. A total of 51 responses were received, representing a $63.75 \%$ response rate. Unfortunately, obtaining a larger sample size was not possible in this study. However, since the computed margin of error for this sample at a confidence level of $95 \%$ is $8.3 \%$, the sample size was considered acceptable. It is worth mentioning that the sample size in Hoffman and Mehra [18] was 41. Thus, the sample size of the study presented in this paper compares favorably with that reported in an earlier relevant study.

4.2. Analysis Tools. To analyze the data collected, two statistical tools were used: Cronbach's alpha and factor analysis. Cronbach's alpha is a coefficient of reliability that is generally used to measure the internal consistency or reliability of a psychometric instrument. It indicates the extent to which a set of test items can be treated as measuring a single latent variable. Its value ranges between zero and one. The closer the Cronbach's alpha coefficient is to one, the greater the internal consistency of the items in the scale is.

Factor analysis is a statistical technique that enables a user to see whether an underlying pattern of relationships exists in a certain dataset, such that the data may be rearranged or reduced to smaller sets of interpretable factors. These factors are independent and account for the variance in the original data.

Factor analysis involves the following steps.

\section{Step 1. The Generation of a Correlation Matrix for the Attrib-} utes.

Step 2. The Extraction of Initial Factors. Factor analysis uses various methods to determine the minimum number of factors that would satisfactorily produce the correlation between the variables. These methods include common factor analysis, principal components analysis, image factor analysis, and canonical factor analysis. However, principal components analysis (PCA) is the most widely used method [22]. In this method, a set of attributes is linearly transformed into a number of factors (principal components), such that the transformed factors are independent. The first factor accounts for the largest amount of variation in the data, the second factor accounts for the next largest amount of variation that is not accounted for by the first, and so on. To extract the factors, (1) is solved for the eigenvalues and the eigenvectors (factor loadings):

$$
(A-I \lambda) Y=0,
$$

where $A$ is the correlation matrix, $I$ is the unit matrix, $\lambda$ is the characteristic root (eigenvalue), and $Y$ is the eigenvector.

Step 3. Rotation to Terminal Factors. To achieve more interpretability, the factors corresponding to the resulting eigenvalues are further rotated by using one of the many rotation techniques, such as the varimax method.

The brief outline of the technique used is presented above only to highlight certain salient features. A detailed mathematical description may be found in the relevant literature.

\section{Analysis of Results}

The analysis of the results for the responses regarding obstacles to productivity improvement is summarized in this section. The results are summarized under two headings:

(i) Reliability Testing Results,

(ii) Factor Analysis Results.

5.1. Reliability Testing Results. The computed Cronbach's alpha coefficient value was 0.93 . This value was considered acceptable because it exceeded the minimum acceptable level of 0.70 [23].

5.2. Factor Analysis Results. In order to reduce the 15 obstacle criteria into a smaller set of factors, the responses were analyzed in order to yield the correlation matrix shown in Table 1. The correlations were further analyzed for eigenstructures and eigenvalues. Table 2 shows the first-stage computation results of the PCA procedure using SPSS/PC. This table contains the percentage of variance attributable to each of the factors. In Table 2, 
TABLE 1: Correlation matrix.

\begin{tabular}{|c|c|c|c|c|c|c|c|c|c|c|c|c|c|c|c|}
\hline & $\mathrm{O}_{1}$ & $\mathrm{O}_{2}$ & $\mathrm{O}_{3}$ & $\mathrm{O}_{4}$ & $\mathrm{O}_{5}$ & $\mathrm{O}_{6}$ & $\mathrm{O}_{7}$ & $\mathrm{O}_{8}$ & $\mathrm{O}_{9}$ & $\mathrm{O}_{10}$ & $\mathrm{O}_{11}$ & $\mathrm{O}_{12}$ & $\mathrm{O}_{13}$ & $\mathrm{O}_{14}$ & $\mathrm{O}_{15}$ \\
\hline $\mathrm{O}_{1}$ & 1.00 & & & & & & & & & & & & & & \\
\hline $\mathrm{O}_{2}$ & .637 & 1.00 & & & & & & & & & & & & & \\
\hline $\mathrm{O}_{3}$ & .270 & .445 & 1.00 & & & & & & & & & & & & \\
\hline $\mathrm{O}_{4}$ & .352 & .499 & .624 & 1.00 & & & & & & & & & & & \\
\hline $\mathrm{O}_{5}$ & .605 & .436 & .532 & .467 & 1.00 & & & & & & & & & & \\
\hline $\mathrm{O}_{6}$ & .300 & .376 & .442 & .277 & .357 & 1.00 & & & & & & & & & \\
\hline $\mathrm{O}_{7}$ & .358 & .508 & .787 & .595 & .576 & .469 & 1.00 & & & & & & & & \\
\hline $\mathrm{O}_{8}$ & .392 & .538 & .598 & .438 & .382 & .445 & .616 & 1.00 & & & & & & & \\
\hline $\mathrm{O}_{9}$ & .380 & .473 & .725 & .494 & .430 & .391 & .617 & .545 & 1.00 & & & & & & \\
\hline $\mathrm{O}_{10}$ & .513 & .415 & .688 & .497 & .589 & .348 & .683 & .524 & .602 & 1.00 & & & & & \\
\hline $\mathrm{O}_{11}$ & .575 & .571 & .501 & .297 & .446 & .605 & .501 & .411 & .495 & .518 & 1.00 & & & & \\
\hline $\mathrm{O}_{12}$ & .451 & .467 & .694 & .539 & .507 & .406 & .658 & .570 & .530 & .637 & .576 & 1.00 & & & \\
\hline $\mathrm{O}_{13}$ & .206 & .420 & .256 & .331 & .429 & .358 & .441 & .283 & .160 & .338 & .411 & .234 & 1.00 & & \\
\hline $\mathrm{O}_{14}$ & .262 & .399 & .492 & .345 & .509 & .475 & .530 & .245 & .381 & .367 & .529 & .415 & .533 & 1.00 & \\
\hline $\mathrm{O}_{15}$ & .150 & .424 & .711 & .501 & .387 & .452 & .636 & .608 & .631 & .422 & .443 & .552 & .443 & .559 & 1.00 \\
\hline
\end{tabular}

TABLE 2: Percentage of variance associated with each factor.

\begin{tabular}{lccc}
\hline Factor & \multicolumn{3}{c}{ Initial eigenvalues } \\
& Total & 51.281 & 51.281 \\
\hline 1 & 7.692 & 8.721 & 60.002 \\
2 & 1.308 & 8.128 & 68.129 \\
3 & 1.219 & 5.897 & 74.026 \\
4 & 0.885 & 5.018 & 79.044 \\
5 & 0.753 & 3.778 & 82.822 \\
6 & 0.567 & 3.285 & 86.107 \\
7 & 0.493 & 3.064 & 89.171 \\
8 & 0.460 & 2.826 & 91.997 \\
9 & 0.424 & 2.080 & 94.078 \\
10 & 0.312 & 1.607 & 95.685 \\
11 & 0.241 & 1.298 & 96.983 \\
12 & 0.195 & 1.265 & 98.248 \\
13 & 0.190 & 1.087 & 99.335 \\
14 & 0.163 & 0.665 & 100.000 \\
15 & 0.100 & &
\end{tabular}

(i) the factors are arranged in descending order of associated variance,

(ii) an eigenvalue greater than or equal to 1 criterion (Kaiser's rule) indicates that only three factors are needed to account for most of the variation.

The procedure further computed an initial factor matrix, which is presented in Table 3. The application of the varimax rotation technique has optimized this matrix and yielded the final rotated matrix, which is shown in Table 4.

Table 4 shows that the factor analysis has reduced the 15 criteria into the following three factors.

Factor 1. This factor explains $51.28 \%$ of the variance in the dataset. As weak middle managers $\left(\mathrm{O}_{3}\right)$, the decline in the work ethic $\left(\mathrm{O}_{4}\right)$, poor employee relations $\left(\mathrm{O}_{7}\right)$, weakness
TABLE 3: Initial factor matrix.

\begin{tabular}{lccc}
\hline & & Factor & \\
& 1 & 2 & 3 \\
\hline $\mathrm{O}_{1}$ & 0.591 & 0.496 & -0.560 \\
$\mathrm{O}_{2}$ & 0.703 & 0.306 & -0.191 \\
$\mathrm{O}_{3}$ & 0.839 & -0.399 & 0.029 \\
$\mathrm{O}_{4}$ & 0.683 & -0.210 & -0.089 \\
$\mathrm{O}_{5}$ & 0.711 & 0.254 & -0.127 \\
$\mathrm{O}_{6}$ & 0.617 & 0.198 & 0.282 \\
$\mathrm{O}_{7}$ & 0.851 & -0.191 & 0.074 \\
$\mathrm{O}_{8}$ & 0.717 & -0.221 & -0.122 \\
$\mathrm{O}_{9}$ & 0.748 & -0.313 & -0.126 \\
$\mathrm{O}_{10}$ & 0.771 & -0.083 & -0.252 \\
$\mathrm{O}_{11}$ & 0.730 & 0.370 & 0.002 \\
$\mathrm{O}_{12}$ & 0.783 & -0.154 & -0.170 \\
$\mathrm{O}_{13}$ & 0.523 & 0.399 & 0.504 \\
$\mathrm{O}_{14}$ & 0.649 & 0.242 & 0.491 \\
$\mathrm{O}_{15}$ & 0.748 & -0.306 & 0.374 \\
\hline
\end{tabular}

in industrial and manufacturing engineering $\left(\mathrm{O}_{8}\right)$, a piecemeal, unplanned approach to improving productivity $\left(\mathrm{O}_{9}\right)$, inadequate/ineffective coordination among departments or functional areas $\left(\mathrm{O}_{10}\right)$, poorly trained supervisory personnel in the area of productivity-related problems $\left(\mathrm{O}_{12}\right)$, and the impossibility of program implementation $\left(\mathrm{O}_{15}\right)$ are its chief contributors, with criteria loadings of $0.884,0.654,0.751$, $0.690,0.775,0.650,0.698$, and 0.723 , respectively, this factor may be termed "poor management practices."

Factor 2. This factor explains $8.72 \%$ of the variance in the dataset. As insufficient capital for improving plants and equipment $\left(\mathrm{O}_{6}\right)$, high worker turnover $\left(\mathrm{O}_{13}\right)$, and the lack of a loyal workforce $\left(\mathrm{O}_{14}\right)$ are its chief contributors, with criteria loadings of $0.595,0.807$, and 0.790 , respectively, this factor may be termed "employee job dissatisfaction." 
TABLE 4: Rotated factor matrix.

\begin{tabular}{lccc}
\hline & & Factor & \\
& 1 & 2 & 3 \\
\hline $\mathrm{O}_{1}$ & 0.161 & 0.062 & 0.938 \\
$\mathrm{O}_{2}$ & 0.335 & 0.319 & 0.640 \\
$\mathrm{O}_{3}$ & 0.884 & 0.254 & 0.133 \\
$\mathrm{O}_{4}$ & 0.654 & 0.168 & 0.249 \\
$\mathrm{O}_{5}$ & 0.369 & 0.350 & 0.572 \\
$\mathrm{O}_{6}$ & 0.299 & 0.595 & 0.234 \\
$\mathrm{O}_{7}$ & 0.751 & 0.382 & 0.237 \\
$\mathrm{O}_{8}$ & 0.690 & 0.155 & 0.280 \\
$\mathrm{O}_{9}$ & 0.775 & 0.127 & 0.241 \\
$\mathrm{O}_{10}$ & 0.650 & 0.139 & 0.472 \\
$\mathrm{O}_{11}$ & 0.295 & 0.507 & 0.570 \\
$\mathrm{O}_{12}$ & 0.698 & 0.178 & 0.383 \\
$\mathrm{O}_{13}$ & 0.076 & 0.807 & 0.173 \\
$\mathrm{O}_{14}$ & 0.274 & 0.790 & 0.145 \\
$\mathrm{O}_{15}$ & 0.723 & 0.515 & -0.072 \\
\hline
\end{tabular}

Factor 3. This factor explains $8.128 \%$ of the variance in the dataset. As insufficient investment in workforce training $\left(\mathrm{O}_{1}\right)$, poor financial controls and/or information systems $\left(\mathrm{O}_{2}\right)$, the lack of a clear connection between employee effort and rewards $\left(\mathrm{O}_{5}\right)$, and insufficient investment in management and supervisor training and development $\left(\mathrm{O}_{11}\right)$ are its chief contributors, with criteria loadings of $0.938,0.640$, 0.570 , and 0.572 , respectively, this factor may be termed "poor human resource management (HRM) practices."

\section{Discussion and Managerial Implications}

Based on the above factor analysis results, three major factors are identified as obstacles to productivity improvement programs in manufacturing enterprises in Oman: (1) poor management practices, (2) employee job dissatisfaction, and (3) poor HRM practices.

6.1. Poor Management Practices. In a study by Bloom and Reenen [24] that investigated the causes and implications of variation in productivity across firms and countries, it was found that differences in management practices account for a significant proportion of the differences in productivity between firms and countries. In addition to being more productive, firms with better management practices tend to grow faster and have higher survival rates. Consistent with this finding, the factor analysis results show that, because they account for the highest variance in the dataset, poor management practices are considered to be the most important obstacle to productivity improvement programs in the manufacturing enterprises in Oman. Improper planning, supervisors who lack an understanding of productivity, poor employee relations, and poor coordination are examples of poor management practices. Improving such practices starts with selecting managers with previous leadership responsibilities and an ability to plan, organize, direct, and control the tasks, people, and resources involved in productivity improvement programs. To perform effectively, the selected managers must be given full authority to design and implement productivity improvement programs.

6.2. Employee Job Dissatisfaction. The second important obstacle to productivity improvement in Oman is employee job dissatisfaction. Therefore, in order to make productivity improvement efforts effective, it is necessary to improve employee job satisfaction. This is because the performance of employees depends not only on skills and knowledge but also on their attitudes toward the job. If their attitudes are positive and there is internal satisfaction with the job, there will be a sense of commitment and loyalty. The link between employee job satisfaction and performance has been addressed by other studies such as Graham [25], Spector [26], Steindel and Stiroh [27], and Crossman and Abou-Zaki [15]. The main findings of these studies are as follows:

(i) unhappy employees are less productive and more likely to have higher absence rates;

(ii) satisfied employees are more productive, innovative, and loyal;

(iii) increased job satisfaction leads to increased employee morale, which, in turn, leads to increased employee productivity;

(iv) increased job dissatisfaction leads to increased employee turnover.

Therefore, in order to increase a productivity improvement program's chance of success, managers should ensure job satisfaction for employees by addressing specific needs such as salaries, health, and safety.

6.3. Poor HRM Practices. The third important obstacle to productivity improvement in Oman is poor HRM practices. The association between productivity and HRM practices has been reported in several studies, including MacDuffie and Krafcik [28], Arthur [29], Huselid [30], Youndt et al. [31], Hoque [32], and Paul and Anantharaman [33].

The training of employees is perhaps the most important aspect of HRM. Unfortunately, the results show that manufacturing enterprises in Oman do not invest sufficiently in the training of employees at all levels. This might be due to the fact that the majority of employees are expatriates who are hired on limited-duration work contracts, and they usually have limited access to training and career development. It is worth mentioning that the problem of low investment in training is not unique to the manufacturing enterprises in Oman; it is a common problem in developing countries.

Because they have a shortage of skilled workers, the need for investment in training in Oman and other developing countries is more pressing than in developed countries [34]. However, to create a greater incentive for enterprises to invest in training [35], Oman's employment and labor laws must be reformed to allow longer-term contacts with expatriate employees.

Another poor HRM practice that is revealed by this study is the lack of a reward and incentive system that rewards employees based on their efforts. According to Bau and Dowling [36], a reward and incentive system includes all monetary 
and nonmonetary rewards and incentives that are provided by an organization to its employees. Unfortunately, there is not a general reward structure that can be implemented by all enterprises; it could vary from one enterprise to another depending on factors such as enterprise size, enterprise age, employees' genders, employees' levels of education, and cultural differences $[36,37]$.

\section{Conclusions}

The literature review in this paper revealed that several studies have been conducted to investigate the factors affecting productivity in various industries. However, only the studies by Hoffman and Mehra [18] and Rantanen [4] have dealt with obstacles to productivity improvement. Furthermore, there has been no study that has investigated this issue in developing countries. This paper presented the results of an empirical study aimed at exploring this issue in developing countries, using Oman as a case study.

Data required for this study were collected from 51 randomly selected manufacturing enterprises using a survey questionnaire. The results of applying factor analysis showed that 15 obstacles to productivity improvement programs could be represented by three major factors. Ranked in order of importance, these factors are (1) poor management practices, (2) employee job dissatisfaction, and (3) poor HRM practices. Therefore, in order to improve the chances of conducting a successful productivity improvement program, the following actions are recommended.

(i) Those people appointed as managers of productivity improvement programs should possess good leadership skills and the ability to plan, organize, coordinate, and control program activities.

(ii) Organizations should find ways to improve their employees' job satisfaction not only by meeting "extrinsic" needs, such as pay, benefits, and other tangible advantages, but also through "intrinsic" needs such as the need for involvement, recognition, control, and freedom.

(iii) Sound human resource management (HRM) practices, including training and the implementation of a good incentive and reward system, are essential in making productivity improvement efforts effective. These practices should be supported by reforming Oman's employment and labor laws to allow longerterm contacts with expatriate employees.

Although the main contribution of the research study lies in exploring obstacles to productivity improvement programs in manufacturing enterprises in Oman, the findings most likely also apply to enterprises in other developing countries operating in an environment similar to Oman's, such as the GCC countries. In addition to multiculturalism, these countries have relatively similar political systems and share a common language, religion, and social values as well as common economic features such as high dependency on oil and gas revenues and heavy reliance on expatriate labor in the private sector.

Finally, although the sample size used in this study compares favorably with that in an earlier study, additional empirical studies are necessary to validate the generality of this study's results. Also, as a complement to this research, there are several areas of particular interest for future research, including

(i) identifying the determinants of job satisfaction among employees in manufacturing enterprises in Oman,

(ii) investigating the association between enterprise size and obstacles to productivity improvement programs; as compared to large enterprises, small enterprises are usually short of capital and skilled staff and have little market influence and only short-term objectives,

(iii) investigating the association between the type of ownership and obstacles to productivity improvement programs; as compared to private enterprises, government-owned enterprises are less flexible, have more bureaucratic decision-making processes, and usually lack skilled staff; however, governmentowned enterprises usually do not face shortages of funds,

(iv) investigating the external obstacles restraining productivity improvement programs in manufacturing enterprises.

\section{Conflict of Interests}

The authors declare that there is no conflict of interests regarding the publication of this paper.

\section{References}

[1] G. R. Bitran and L. Chang, "Productivity measurement at the firm level," Interfaces, vol. 14, no. 3, pp. 29-40, 1984.

[2] A. Kazaz and S. Ulubeyli, "Drivers of productivity among construction workers: a study in a developing country," Building and Environment, vol. 42, no. 5, pp. 2132-2140, 2007.

[3] S. Eilon, "A framework for profitability and productivity measure," Interfaces, vol. 15, no. 3, pp. 31-40, 1985.

[4] H. Rantanen, "Internal obstacles restraining productivity improvement in small Finnish industrial enterprises," International Journal of Production Economics, vol. 69, no. 1, pp. 85-91, 2001.

[5] S. R. Sanders and H. R. Thomas, "Factors affecting masonrylabor productivity," Journal of Construction Engineering and Management, vol. 117, no. 4, pp. 626-644, 1991.

[6] M. R. Abdul Kadir, W. P. Lee, M. S. Jaafar, S. M. Sapuan, and A. A. A. Ali, "Factors affecting construction labour productivity for Malaysian residential projects," Structural Survey, vol. 23, no. 1, pp. 42-54, 2005.

[7] H. M. Alinaitwe, J. A. Mwakali, and B. Hansson, "Factors affecting the productivity of building craftsmen - studies of Uganda," Journal of Civil Engineering and Management, vol. 13, no. 3, pp. 169-176, 2007.

[8] A. Enshassi, S. Mohamed, Z. A. Mustafa, and P. E. Mayer, "Factors affecting labour productivity in building projects in the Gaza strip," Journal of Civil Engineering and Management, vol. 13, no. 4, pp. 245-254, 2007. 
[9] P. W. Chan and A. Kaka, "Productivity improvements: understand the workforce perceptions of productivity first," Personnel Review, vol. 36, no. 4, pp. 564-584, 2007.

[10] J. Dai, P. Goodrum, and W. Maloney, "Construction craft workers' perceptions of the factors affecting their productivity," Journal of Construction Engineering and Management, vol. 135, no. 3, pp. 217-226, 2009.

[11] A. A. Shikdar and N. M. Sawaqed, "Worker productivity, and occupational health and safety issues in selected industries," Computers and Industrial Engineering, vol. 45, no. 4, pp. 563$572,2003$.

[12] H.-J. Steenhuis and E. J. de Bruijn, "International shop floor level productivity differences: an exploratory study," Journal of Manufacturing Technology Management, vol. 17, no. 1, pp. 42-55, 2006.

[13] D. G. Carnevale, "Physical settings of work: a theory of the effects of environmental form," Public Productivity and Management Review, vol. 15, no. 4, pp. 423-436, 1992.

[14] A. Leaman, "Dissatisfaction and office productivity," Journal of Facilities Management, vol. 13, no. 2, pp. 3-19, 1995.

[15] A. Crossman and B. Abou-Zaki, "Job satisfaction and employee performance of Lebanese banking staff," Journal of Managerial Psychology, vol. 18, no. 4, pp. 368-376, 2003.

[16] A. Hameed and S. Amjad, "Impact of office design on employees productivity: a case study of banking organizations of Abbottabad, Pakistan," Journal of Public Affairs Administration, vol. 3, no. 1, pp. 1-13, 2009.

[17] L. Lan, Z. Lian, and L. Pan, "The effects of air temperature on office workers' well-being, workload and productivityevaluated with subjective ratings," Applied Ergonomics, vol. 42, no. 1, pp. 29-36, 2010.

[18] J. M. Hoffman and S. Mehra, "Operationalizing productivity improvement programs through total quality management," International Journal of Quality \& Reliability Management, vol. 16, no. 1, pp. 72-84, 1999.

[19] M. K. Groover, Automation, Production Systems, and ComputerIntegrated Manufacturing, Prentice Hall, Upper Saddle River, NJ, USA, 2001.

[20] “Petrochem industry accounts for 5.5pc of GDP," Oman Daily Observer, 2013.

[21] S. F. Olejnik, "Planning educational research: determining the necessary sample size," The Journal of Experimental Education, vol. 53, no. 1, pp. 40-48, 1984.

[22] D. G. Kleinbaum and L. L. Kupper, Applied Regression Analysis and Other Multivariable Methods, Duxbury Press, Massachusetts, Mass, USA, 1998.

[23] J. C. Nunnally and I. H. Bernstein, Psychometric Theory, McGraw-Hill, New York, NY, USA, 1994.

[24] N. Bloom and J. V. Reenen, "Why do management practices differ across firms and countries?" The Journal of Economic Perspectives, vol. 24, no. 1, pp. 203-224, 2010.

[25] B. W. Graham, “The business argument for flexibility, $H R$ Magazine, vol. 41, no. 5, p. 104, 1996.

[26] P. Spector, Job Satisfaction: Application, Assessment, Cause and Consequences, Sage, London, UK, 1997.

[27] C. Steindel and K. J. Stiroh, "Productivity: what is it and why do we care about it?" Business Economics, vol. 36, no. 4, pp. 12-31, 2001.
[28] J. P. MacDuffie and J. F. Krafcik, "Integrating technology and human resources for high performance manufacturing: evidence from the international auto industry," in Transforming Organizations, T. A. Kochan and M. Useem, Eds., Oxford University Press, New York, NY, USA, 1992.

[29] J. B. Arthur, "Effects of human resource systems on manufacturing performance and turnover," Academy of Management Journal, vol. 37, no. 3, pp. 670-687, 1994.

[30] M. A. Huselid, "The impact of human resource management practices on turnover, productivity, and corporate financial performance," Academy of Management Journal, vol. 38, no. 3, pp. 635-672, 1995.

[31] M. A. Youndt, S. A. Snell, J. W. Dean Jr., and D. P. Lepak, "Human resource management, manufacturing strategy, and firm performance," Academy of Management Journal, vol. 39, no. 4, pp. 836-866, 1996.

[32] K. Hoque, "Human resource management and performance in the UK hotel industry," British Journal of Industrial Relations, vol. 37, no. 3, pp. 419-443, 1999.

[33] A. K. Paul and R. N. Anantharaman, "Impact of people management practices on organizational performance: analysis of a causal model," International Journal of Human Resource Management, vol. 14, no. 7, pp. 1246-1266, 2003.

[34] R. Almeida and R. Aterido, "The incentives to invest in job training: do strict labour codes influence this decision?" The World Bank Social Protection Discussion Papers 46189, 2008.

[35] E. Wasmer, "Interpreting Europe-US labor market differences: the specificity of human capital investments," American Economic Review, vol. 96, no. 3, pp. 811-831, 2006.

[36] F. Bau and M. Dowling, "An empirical study of reward and incentive systems in German entrepreneurial firms," Schmalenbach Business Review, vol. 59, pp. 160-175, 2007.

[37] R. S. Allen, M. B. Takeda, C. S. White, and M. M. Helms, "Rewards and organizational performance in Japan and the United States: a comparison," Compensation \& Benefits Review, vol. 38, no. 1, pp. 7-14, 2004. 

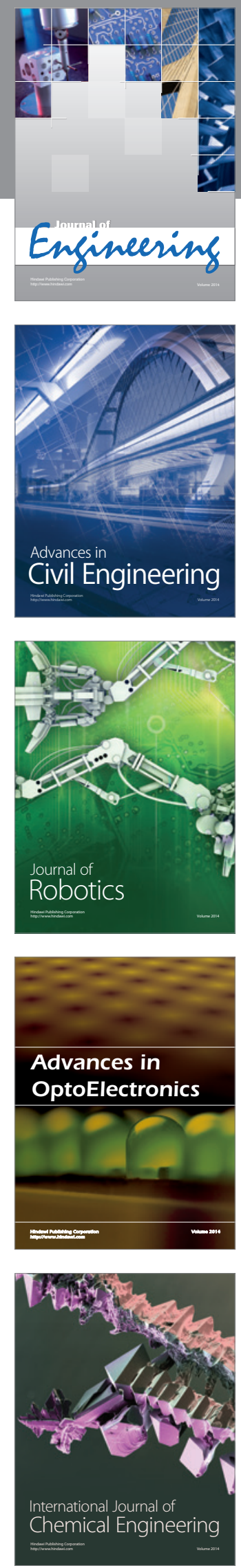

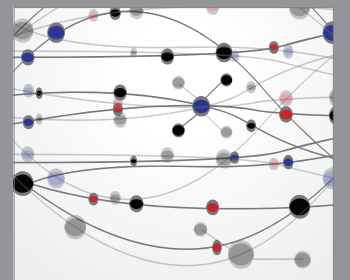

The Scientific World Journal
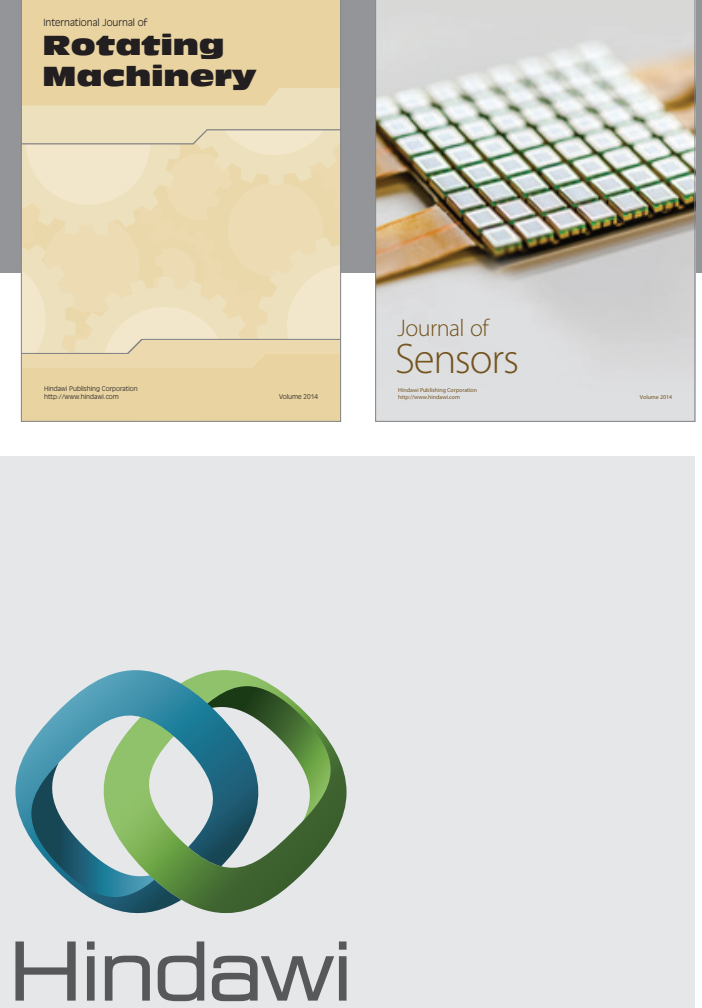

Submit your manuscripts at http://www.hindawi.com
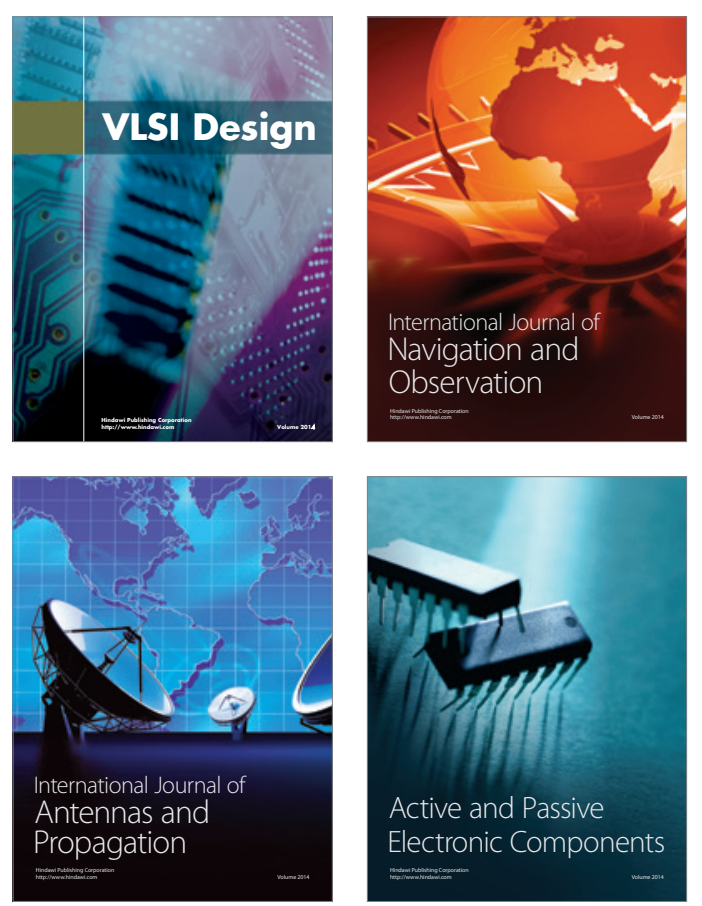
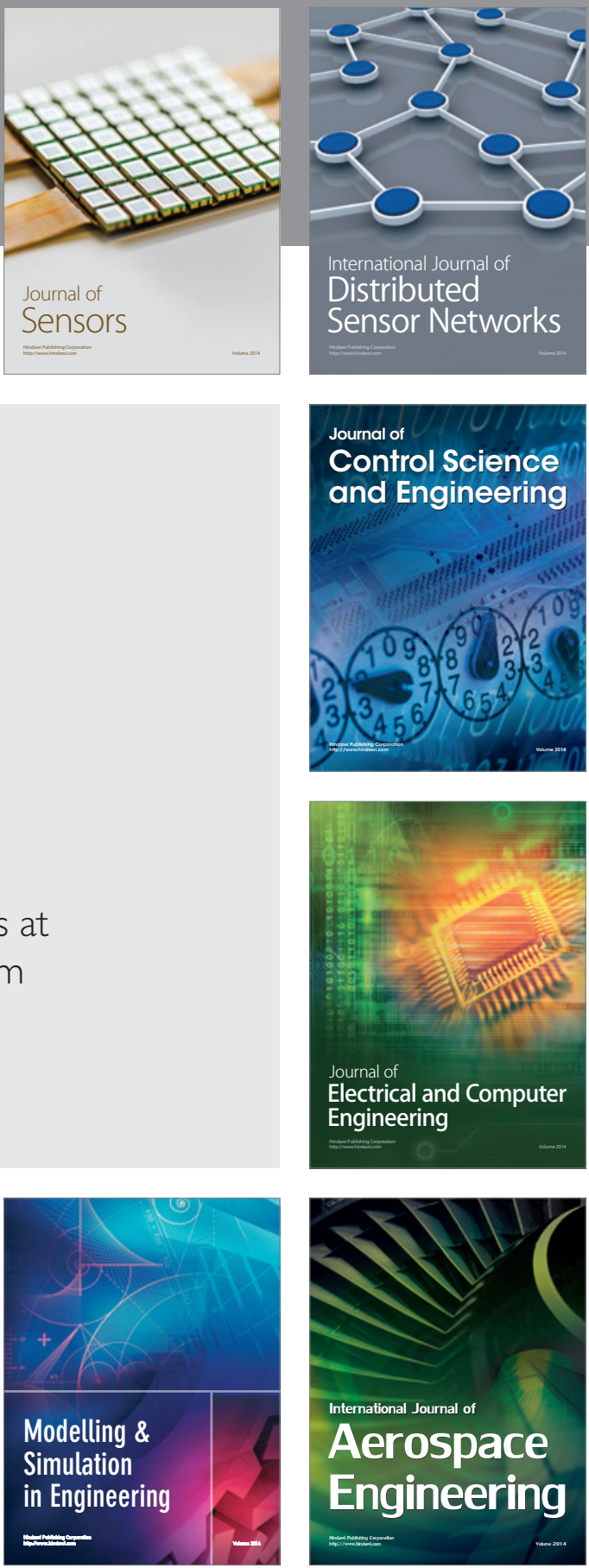

Journal of

Control Science

and Engineering
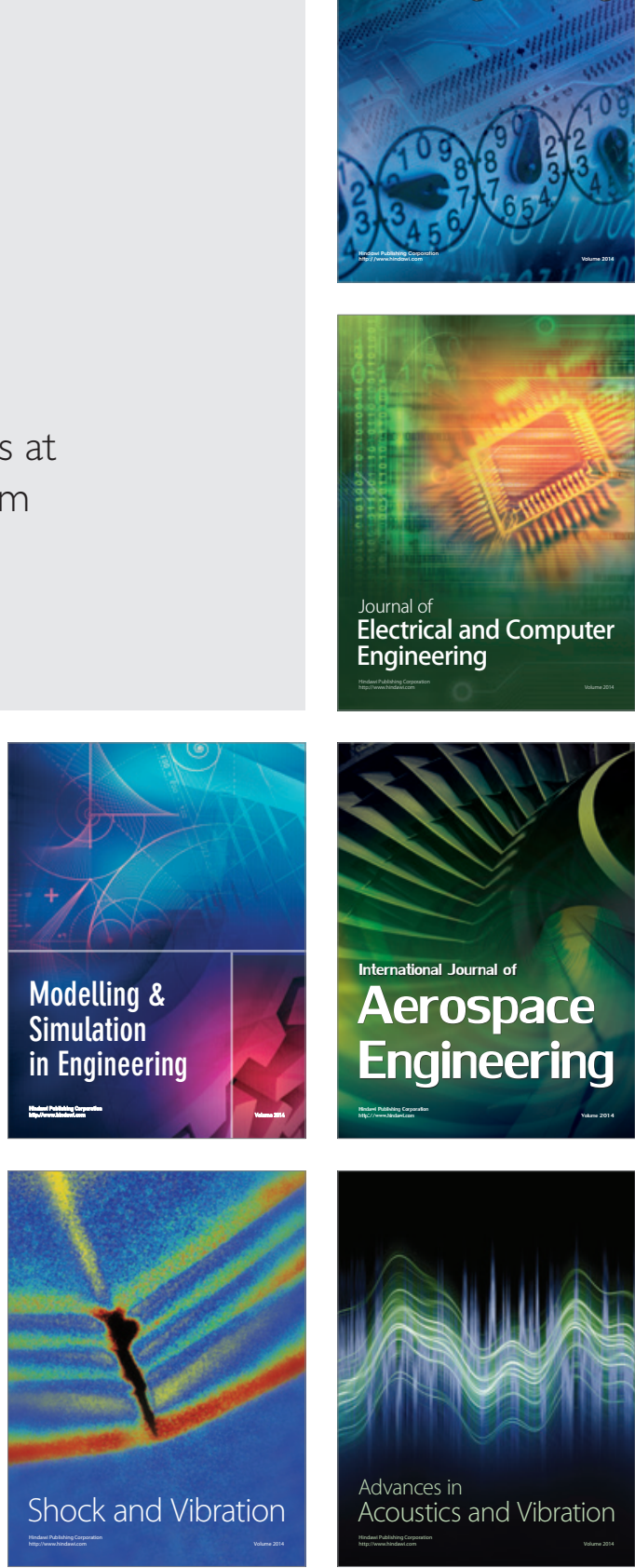